\title{
Aroha, Manaakitanga, Whanaungatanga: Social work educators' reflections on the Covid-19 lockdown in Aotearoa New Zealand
}

Nathan Jaquiery, Marissa Kaloga and Susan Wason, University of Otago, Aotearoa New Zealand

The 2020 Covid-19 pandemic which, as at the time of writing, is ongoing throughout the world, has far-reaching implications for the practice of social work. As Aotearoa New Zealand steadily moves towards declaring itself "Covid-free," it is important to reflect upon and capture the complexities, challenges, and dynamics experienced during the lockdown. As the pandemic continues to expand, front-line experiences can serve to inform decision making and reflection on the future development of the social work profession in a post-Covid world. This article will discuss the experiences of three social work educators at the University of Otago's Social and Community Work Programme. Each contributor will relate their pandemic teaching and learning experience by aligning it with a Value and Ethical Principle of the Aotearoa New Zealand Association of Social Work Code of Ethics (ANZASW, 2019). Each contributor felt that it was important to capture their experiences during this defining moment in our history and to consider how the nature of relationships may have changed, how boundaries shifted and learning has ensued as we have journeyed through a shared traumatic experience together. "He waka eke noa" (we are all in this together)

The Level 4 lockdown $1^{\mathrm{i}}$ began on 26 March 2020, 12am, three weeks after the semester began on campus. This lockdown was accompanied by extremely tight restrictions on movement and social contact, necessitating all university courses and functions to be immediately moved online. The following sections detail the experiences of Susan Wason, Field Education Coordinator; Nathan Jaquiery, Professional Practice Fellow; and Marissa Kaloga, Lecturer. Reflecting on these last three months, the devastating effects of Covid-19 and the associated emotional implications of the trauma of the pandemic, suggest that the need for social workers in our communities will increase. Enabling a path for the current cohort of students due to graduate this year, is therefore crucial.

\section{Aroha during a pandemic: \\ Susan Wason, Field Education Coordinator}

\begin{abstract}
Social Workers acknowledge our mutual responsibility for wellbeing. We recognise our common humanity with people who use our services and hold people to account, using professional judgement without being judgemental. We focus on people's strengths and finding solutions. (ANZASW, 2019, p. 12)
\end{abstract}

As a Field Education Coordinator for the Social and Community Work programme, I was in the midst of arranging placements for students when the first stirrings of Covid-19 began. During early March, I had completed meetings with students and discussed their hopes for the final placement of their social work qualification. As the presence of Covid-19 in Aotearoa New Zealand grew and the prospect of lockdown loomed, I had serious concerns about the viability of these second-semester placements. Firstly, if the country remained in lockdown for
AOTEAROA NEW ZEALAND SOCIAL WORK 32(2), 65-70.

CORRESPONDENCE TO: Nathan Jaquiery nathan.jaquiery@ otago.ac.nz 
an extended period, placements would be unlikely to occur. Secondly, organisations once open to placements might no longer be in a position to host students regardless of the alert level. Thirdly, if organisations did agree to have students, health and safety considerations would necessitate significant planning.

Over the Level 4 lockdown period, both the university and the Social Workers Registration Board (SWRB) developed policies to address health and safety and to support and underpin student placements during the Covid-19 period (SWRB, 2020; University of Otago, 2020). With these policies outlined, and as we moved closer to Level 3, I was then able to continue pursuing placement opportunities for students.

Our organisational partners were integral to the continuity of the placement programme throughout Covid-19. Their willingness to provide placements for students during this difficult time is significant, as they continued to provide a service for which there is no financial gain or recompense. I believe this willingness to continue to engage in placements is due to both the calibre of past students and the relationships established over many years between the University of Otago Social and Community Work programme and the social service organisations in our communities. The social workers and others in associated professions with whom we place students are willing to give their time, energy, knowledge and skills to support the continued development of social work professionals. Relationships have always underpinned placement practice, but a Covid-19 world reiterated their importance and value.

Upon reflection of this semester, the values and ethical principles of social work practice outlined in the Aotearoa New Zealand Association of Social Workers (ANZASW) Code of Ethics underpinned and guided my practice throughout the lockdown situation and the period following (ANZASW, 2019). While negotiating and renegotiating placements, the value of aroha and its associated ethical principles were apparent (ANZASW, 2019). Organisational partners were solution focused, as shown by their overwhelming agreement to have students on placement during difficult circumstances. I was concerned that social workers in frontline practice would be thinking, "How can she be thinking about placements at a time like this?" I anticipated difficult conversations, but this did not play out in reality. The needs of others were clearly at the forefront of social workers' minds (ANZASW, 2019). By agreeing to student placements, there was clear acknowledgement of the value of students and the need to provide opportunities for them to complete their placements, making way for the next generation of social workers. Social workers, in their everyday work, contribute toward making society more socially just and inclusive. Developing the skills of social work students invests in the future knowledge of the social work profession.

I learnt during this time of crisis, that our social work community partners "come through," even when having a student on placement might be the last thing on a field educator's mind. There is an innate sense of paying it forward and providing an opportunity for students to learn. I have appreciated the patience and understanding of students as the placement pathway was negotiated, delayed and renegotiated. As we move down the Covid-19 alert levels, I am hopeful that the majority of placements will go ahead, albeit with a potential delay for some.

After Covid-19, I anticipate that social work placements will operate differently. We will be more prepared for the unexpected. Placements will include plans for contingencies, such as different "alert levels," and working from home options when possible. At this stage, it appears that 2020 placements will occur in organisations as originally planned, however some will have a greater project focus. Adaptability 
in the face of possible COVID-19 alert level changes will be important factors to be considered in these placements. The new experience of negotiating and renegotiating placements under Covid-19 has shown that the social work profession is adaptable, flexible and committed to growing the next generation of social workers, even in the face of great adversity. These are the social workers who will front the future of social work. They are the social workers who will advocate alongside those with whom they work for equity and social justice.

\section{Manaakitanga: Upholding mana}

\section{Nathan Jaquiery, Professional Practice Fellow}

Social workers recognise and support the mana of others. We act towards others with respect, kindness and compassion. We practice empathic solidarity, ensure safe space, acknowledge boundaries and meet obligations. (ANZASW, 2019, p. 11)

Semester 1, 2020 began a "new" year, a "new" semester and a "new" group of third-year (bachelor) and first-year masters (applied) enthusiastic students, eager to learn about the profession of social work. We had taught them only for three weeks when Covid-19 spread throughout the country. Lockdown detained us in our homes, where fear and anxiety gripped us as a nation. There was a universal sentiment that we were "in this pandemic together," but conversely, there was an underlying fear and anxiety held by most people, which was understandable, inevitable and very real.

For some students, the privilege of university study was challenged as they grappled with finances, employment redundancy, "essential service" commitments, panic, confusion and anxiety. Some students and staff were forced to weigh their priorities, rethinking the hierarchy of their obligations, where higher education became less important than fulfilling the basic necessities of life, such as food, clothing and shelter (Maslow, 1943).

Manaakitanga is one of the five values within the Aotearoa New Zealand Association of Social Work (ANZASW) Code of Ethics. Manaakitanga is the action of upholding people's "mana," where respect and compassion and kindness are shown toward people, and where boundaries are recognised (ANZASW, 2019). As social workers and social work educators, to develop trusting, strong, resilient yet professional relationships with students, it is essential that we uphold and model to our students the concept and value of mana, so that they are able to uphold the mana of people who they will eventually work with (ANZASW, 2019).

Following an on-campus to online curriculum overhaul, extra focus was placed on student wellbeing and welfare. I prioritised student "check-ins" at the beginning of each Zoom session that I held, and asked each student to scale how they were feeling, coping, progressing; on a scale of 1 (lowest) to 10 (highest). Scaling questioning techniques are used in solution-focussed and brief therapeutic approaches (de Shazer, 1985). In addition, the Signs of Safety approach (Turnell \& Edwards, 1999) embraces scaling to help determine safety and risk factors within child and family social work practice (de Shazar, 1985; Turnell \& Edwards, 1999). Scaling questions, coupled with appreciative enquiry, enabled me to gauge how students were feeling and what would help them to move to a higher position on the continuum. For example, one question was; "on a scale of $0-10$, where 0 means that academic study for you during Level 4 lockdown is challenging and you feel stressed, anxious or worried that you won't succeed, and 10 means that you feel 100\% motivated, happy and focussed on your study, where would you place yourself on this continuum?" (de Shazar, 1985; Turnell \& Edwards, 1999). Once the students place themselves on the continuum, a response could be "I'm impressed by how you managed through 
these challenges, what would help you move from a ' 6 ' (on the continuum) to an '8'?' (Turnell \& Edwards, 1999). The Zoom sessions were open, allowing students and their peers to be aware of one another's wellbeing, potentially being able to provide peer support if appropriate. If students required more support and pastoral care, I was able to provide one-on-one conversations following the teaching sessions. It was of utmost importance that our students felt supported, not only by me as an educator, but also by their peers and their other natural support networks.

Using Zoom as a teaching forum allowed me to continue to teach and have face-toface interaction. However, as a social worker trained with frontline child and family social work practice experience, I became more anxious about privacy and student-toteacher boundaries. I felt that my home was "open for viewing," exacerbated when my young child unwittingly invaded some of these sessions. Adding to this, I felt a sense of discomfiture as the students reciprocated this dynamic. In many ways, a deeper sense of relationship inadvertently transpired through this forum, possibly presenting itself as a boundary concern. I considered utilising the Zoom standard background function, but chose against using it as I felt that we needed to be on a level playing field, so I let them in, as they also did with me.

The social work educator-student relationship is perceptibly different to that of the social worker-client relationship but, through the Covid-19 lockdown experience, that difference was less apparent. For example, some students were struggling and my role was to be there and provide support, a listening ear, reassurance and then assist them in planning out their next steps. Therefore, our relationship became very similar to the role of a social work practitioner-client relationship. "Professional conduct" under manaakitanga ensures that social workers act with integrity, are able to develop trusting relationships, and are aware of professional boundaries and power dynamics within social work roles (ANZASW, 2019). Being able to recognise issues, which potentially impacted an individual's mana, meant that I was able to set my mind at ease somewhat. Being aware of where boundaries lay, and that I wanted the best for my students, I felt compassion, empathy and respect for each student as they individually journeyed through the Covid-19 lockdown experience and beyond.

\section{Whanaungatanga: Teaching community in the time of Covid-19}

\section{Dr Marissa Kaloga, Lecturer}

Social Workers work to strengthen reciprocal mana-enhancing relationships, connectedness and to foster a sense of belonging and inclusion. (ANZASW, 2019, p. 11)

In my two-course series on organisations and communities for our Bachelor of Social Work (BSW) and Master of Community and Social Work (MSCW) students, I take some time to explore the idea of community. It is important to unpack students' internalised understanding, because "community" means many things to many people and it is too often homogenised or essentialised. To do this I use Ruth Liepins (2000) model and definition of community, which places any notion of community within a context of "temporally and locationally specific terrains of power and discourse" (Liepins, 2000 , p. 30). Using this model, students are then able to examine seemingly unified communities and understand them to be complex, heterogeneous, and fluid arenas of social interaction through social work's foundational social justice lens.

The budding learning communities we were co-creating quickly moved online in March in response to the Level 4 Covid-19 restrictions. We then found ourselves in the situation of renegotiating both how our class would function as well as how to maintain 
social relationships in strict lockdown, a new situation for everyone. It was a unique opportunity to approach learning about community development in a completely new context. As a lecturer, I sought to balance several competing factors. I wanted to preserve the integrity of the original course, to seize the transformational learning opportunity this novel context provided, and to be a source of support for students as they struggled with the unique challenges ahead of them.

For one assignment, I gave my students the option to create a self-care plan and write a letter to their future selves about how they planned to maintain their connection with community in light of strict limits on movement and social interaction. It was my hope that taking the time to think through this would help them to develop a plan to manage this new context, and allow them to consider how their communities had changed in response to Covid-19. With limited time and resources, students had to use a strengths-based approach for themselves; to think creatively about how to use what they already had to get through a difficult time.

For many, the concept of community was simultaneously expanded and reduced. Expanded in that the idea of distance was erased due to the necessity to communicate, even with close loved ones, using technology platforms like Zoom, Facebook Messenger, or WhatsApp; the location of their friends became irrelevant and all connections felt equally close/ distant. Conversely, the intensity of physically close community was enhanced. First, the members of one's bubble were everpresent under the restrictions of Level 4 lockdown. Secondly, there was a newfound closeness with immediate neighbours; picking up groceries, cooking meals for elderly neighbours, or having regular chats across the fence with people they had only said "hello" to previously. Community, which before had existed as an inert, feelgood concept, became alive. Community
Development, which before seemed tangential to many social work students, now felt integral.

Reflecting on the semester, my actions and approach to teaching were guided by whanaungatanga. The importance of fostering and supporting social relationships has always been important for social work, but it became vital to be intentional about this during Level 4 lockdown. The idea that community is fluid rather than static, heterogeneous rather than homogeneous, and hierarchical rather than flat, was experienced rather than simply learnt by students during the lockdown. As an instructor during this time, my role expanded beyond simple transference of knowledge; it became equally important to support students' connectedness with their own communities. This renegotiation of the instructorlearner relationship did not feel forced or uncomfortable. Rather, by embracing the ethical principle of whanaungatanga I was able to better embody the kind of communityfocussed, context-dependent practice that was a key objective of the courses.

\section{Conclusion}

Throughout the next few years, the true effects of Covid-19 will be better understood. Until it is controlled, there will continue to be a tragic loss of life, as well as broad and unfolding economic and social ramifications throughout the world. In this reflective piece, we endeavoured to capture our experiences teaching social work during the Level 4 lockdown in the hopes that this in situ knowledge can inform the future development of social work in the postCovid-19 era.

We identified several key takeaways from our experiences as social work educators during the Level 4 lockdown, namely: 1 . The importance of relying on strong professional relationships during crises; 2. Negotiating student/teacher boundaries during a shared traumatic experience; and 3. Encouraging students to apply 
community development principles to their own situations to combat social isolation. We viewed these experiences through the lens of foundational social work ethical principles of practice: 1. Manaakitanga; 2. Aroha; and 3. Whanaungatanga. By linking our ethics with our teaching practice, knowledge of social work theory and equipped with our kete of interpersonal social work tools, we were able to better understand how social work values can support decision making in uncertain contexts, such as teaching in a pandemic environment.

Adversity and other complicating factors may challenge us in our abilities to successfully meet these values and principles; however, with effective social work supervision, awareness and critical reflective ability we are more prepared to respond to challenging situations with wisdom and a calculated response set. As we reflected, it became evident that, through this pandemic nationally and globally, that social work remained adaptable to change, flexible, resilient and steadfast as a profession but also as a philosophy of helping others and of advocating for social and economic justice with marginalised populations.

\section{Note}

i In March 2020 the New Zealand Government announced four levels of alert for the Covid-19 pandemic. These levels specified the actions required and Level 4 was the highest. https://covid19.govt.nz/covid-19/restrictions/ alert-system-overview/

\section{References}

Aotearoa New Zealand Association of Social Workers (ANZASW). (2019). Code of Ethics/ Nga Tikanga Matatika-Aotearoa. Author. Retrieved from https://anzasw.nz/code-of-ethics-2019/

de Shazer, S. (1985). Keys to a solution in brief therapy. A Norton Professional book.. Retrieved from https://www.books.google.co.nz/ books?id=EnmAQgAACAAJ

Liepins, R. (2000). New energies for an old idea: Reworking approaches to "community" in contemporary rural studies. Journal of Rural Studies, 16(1), 23-35.

Maslow, A. H. (1943). A theory of human motivation. Psychological Review, 50(4), 370-396. https://doi.org/10.1037/h0054346.
Radio New Zealand. (2000). Covid-19: New Zealand is now in lockdown. Retrieved from https://www.rnz.co.nz/ news/national/412606/covid-19-new-zealand-is-now-inlockdown

Social Workers Registration Board. (2020). SWRB: Educators programme recognition. Retrieved from https://swrb.govt.nz/education/educators/

Turnell, A., \& Edwards, S. (1999). Signs of safety: A solution and safety oriented approach to child protection casework. Norton, USA.

University of Otago. (2020). Social work placement policy in response to Covid-19. University of Otago, Dunedin, New Zealand. Retrieved from https://www.otago.ac.nz/ social-community-work/study/otago736368.html 